\title{
HAKIKAT PEMBUKTIAN MELALUI MEDIA ELEKTRONIK DALAM PRESPEKTIF SISTEM PERADILAN PIDANA INDONESIA
}

\author{
Muslim Mamulai \\ Mahasiswa Program Pascasarjana Universitas Muslim Indonesia Makassar \\ email : muslim.mamulai@ymail.com
}

\begin{abstract}
Proof via electronic media in criminal trials, still based on the provisions contained in the Code of Criminal Procedure, namely with reference to the theory of proof under the law negatively, but in practice there is still a criminal trial the pros and cons. However, in fact the truth of the witness examination teleconference remain equal value, with a witness who was not present at the trial because the witness has been sworn in.

Keywords: Electronic Media in the criminal justice system.
\end{abstract}

\begin{abstract}
Abstrak
Pembuktian melalui media elektronik dalam persidangan pidana, masih didasarkan pada ketentuan yang terdapat dalam Kitab Undang-Undang Hukum Acara Pidana, yaitu dengan mengacu pada teori pembuktian berdasarkan hukum secara negatif, tetapi dalam praktiknya masih ada persidangan pidana pro dan kontra. Namun, sebenarnya kebenaran teleconference dari pemeriksaan saksi tetap bernilai sama, dengan saksi yang tidak hadir di persidangan karena telah saksi telah ditetapkan.

Kata kunci: media elektronik; sistem; peradilan pidana
\end{abstract}

\section{A. PENDAHULUAN}

Seiring dengan perkembangan masyarakat dan teknologi, semakin meningkat pula penggunaan alat elektronik digital. Karena itu, untuk menghadapi kenyataan tersebut maka hukum haruslah mampu untuk mengaturnya, terutama kekuatan pembuktian dari suatu media elektronik dalam suatu peradilan pidana. Namun demikian, secara faktual terjadi kecenderungan manipulasi penggunaan alat bukti digital oleh pihak-pihak yang tidak bertanggung jawab.

Dilema penegakan hukum pembuktian melalui media elektronik ini, disebabkan Kitab Undang-undang Hukum Acara Pidana (KUHAP) yang berlaku di Indonesia belum mengakomodir tentang pembuktian melalui media elektronik. Hal itu tercermin dalam Pasal 184 ayat (1) KUHAP, yang "hanya" menyebutkan bahwa Alat bukti yang sah ialah:
a. keterangan saksi;
b. keterangan ahli;
c. surat;
d. petunjuk; 
e. keterangan terdakwa.

Dengan terbatasnya alat bukti tersebut, maka keberadaan bukti melalui media elektronik menimbulkan kontroversi yang berkepanjangan, terlebih lagi dalam Pasal 183 KUHAP secara tegas menyatakan bahwa : Hakim tidak boleh menjatuhkan pidana kepada seseorang kecuali dengan sekurang-kurangnya dua alat bukti yang sah, ia memperoleh keyakinan bahwa suatu tindak pidana benar-benar terjadi dan bahwa terdakwalah yang melakukannya. Selain itu, dalam Pasal 6 ayat (2) KUHAP yang pada akhirnya mengarah pada Pasal 184 ayat (1) KUHAP yaitu ;

"Tidak seorang pun dapat dijatuhi pidana, kecuali apabila pengadilan, karena alat pembuktian yang sah menurut undang-undang, mendapat keyakinan bahwa seseorang yang dianggap dapat bertanggung jawab, telah bersalah atas perbuatan yang didakwakan atas dirinya".

Dalam perkembangan sistem hukum pidana terkait penggunaan media elektronik sebagai salah satu alat bukti dalam perkara pidana, hal yang menimbulkan kontroversi publik yaitu tentang kewenangan Komisi Pemberantasan Korupsi (KPK) sebagai salah satu lembaga negara yang memiliki kewenangan untuk melakukan penyelidikan, penyidikan dan penuntutan dalam perkara korupsi, kerapkali menggunakan media elektronik sebagai salah satu bukti untuk menjerat para koruptor. Tindakan penyadapan yang dilakukan oleh KPK tersebut, terbukti sangat efektif digunakan untuk mengungkap perkara-perkara korupsi di Indonesia. Selain itu, dalam praktek masih terdapat beberapa bukti elektronik yang dijadikan dasar oleh penyidik dalam memproses suatu tindak pidana, seperti misalnya closed circuit television (CCTV) dan surat elektronik.

Di Indonesia, perkembangan sistem hukum pembuktian khususnya yang menyangkut dengan pembuktian elektronik, tercermin setelah keluarnya UndangUndang Nomor 11 Tahun 2008 tentang Informasi dan Transaksi Elektronik. Jika sebelumnya bukti elektronik hanya dipakai dalam hukum acara perdata sebagai bukti persangkaan atau dalam hukum acara pidana hanya dipergunakan sebagai bukti petunjuk, maka dengan keluarnya UU tentang informasi transaksi elektronik tersebut, alat bukti elektronik berupa informasi elektronik, dokumen elektronik, dan hasil cetakannya dengan tegas di akui sebagai alat bukti. Dengan demikian UU ini, diharapkan dapat menjawab berbagai masalah hukum (termasuk hukum pembuktian), yang berkenaan dengan dunia maya (law of technology information and communication), dan hukum tentang perdagangan dengan memakai elektronik $(e-$ commerce).

Salah satu yang menjadi masalah hukum tentang e-commerce adalah bahwa proses e-commerce belum dapat diakui, baik sebagai bukti oleh hukum secara konversional, seperti yang diatur dalam Hukum Acara Perdata maupun pembuktian pidana dalam Kitab Undang-Undang Hukum Acara Pidana (KUHAP).

Terkait dengan informasi elektronik, dokumen elektronik, dan hasil cetakannya, Undang-Undang Nomor 15 Tahun 2002 tentang Tindak Pidana Pencucian Uang (UUTPPU) telah memasukkan salah satu alat bukti di samping alat bukti yang telah diatur pada Pasal 184 KUHAP. Alat bukti diluar Pasal 184 KUHAP yang diatur dalam UU TPPU terdapat pada Pasal 38 huruf b yang menyatakan :

"alat bukti lain berupa informasi yang diucapkan, dikirim, diterima, atau disimpan 
secara elektronik dengan alat optik atau yang serupa dengan itu”.

Perkembangan tekhnologi berimbas bagi sistem pembuktian, sehingga kebutuhan terhadap bukti elektronik dalam peradilan tindak pidana umum sangat diperlukan. Hal ini, telah diakomodasi dalam RUU KUHAP pada draft bulan Desember Tahun 2012 mengenai bukti elektronik sebagai alat bukti (Pasal 175) yang menyatakan "alat bukti yang sah mencakup : 1 . barang bukti, 2. surat-surat; 3 . bukti elektronik; 4. keterangan seorang ahli; 5. keterangan seorang saksi; 6. keterangan terdakwa; dan 7. pengamatan hakim".

Pengertian alat bukti elektronik menurut Pasal 175 RUU KUHAP, adalah informasi yang diucapkan, dikirim, diterima atau disimpan secara elektronik dengan alat optik atau yang serupa dengan itu, termasuk setiap rekaman data atau informasi yang dilihat, dibaca atau didengar yang dapat dikeluarkan dengan atau tanpa bantuan suatu sarana baik yang tertuang diatas kertas, benda fisik apapun selain kertas maupun yang terekam secara elektronik yang berupa tulisan, gambar, peta, rancangan, foto, huruf, tanda, angka yang memiliki makna.

Dengan realitas yang demikian, maka dengan belum adanya ketentuan yang mengatur tentang keabsahan bukti elektronik pada pembuktian persidangan perkara pidana umum tentu menjadi permasalahan yang dihadapi aparat penegak hukum.

\section{B. ANALISIS DAN PEMBAHASAN}

\section{Hakikat Pembuktian Melalui Media Elektronik Di Persidangan Pidana}

Perkembangan teknologi dewasa ini, dirasakan semakin pesat terutama di bidang komunikasi dan informasi, karena memberikan kemudahan bagi masyarakat untuk berkomunikasi yaitu melalui teleconference yang dihubungkan dengan satu sistem komunikasi dengan menyajikan data-data dengan suatu alat atau lebih alat, seperti telepon, telegraf, televisi, dan lain-lain.

Hukum Acara Pidana sendiri telah mengatur bagaimana cara pembuktian dapat dilakukan dipersidangan, dan bagaimana hakim bersikap di dalam putusannya terhadap suatu perkara. Hal ini, diatur dalam Pasal 183 Undang-Undang Nomor 8 Tahun 1981 tentang Kitab Undang-Undang Hukum Acara Pidana (KUHAP) yang menentukan, "Hakim tidak boleh menjatuhkan pidana kepada seseorang kecuali apabila dengan sekurang-kurangnya dua alat bukti yang sah ia memperoleh keyakinan bahwa suatu tindak pidana benar-benar terjadi dan bahwa terdakwalah yang bersalah melakukannya". Di dalam penjelasan Pasal 183 KUHAP tersebut, hanya menyebutkan "Ketentuan ini adalah untuk menjamin tegaknya kebenaran, keadilan dan kepastian hukum bagi seseorang”. Ketentuan Pasal 183 KUHAP ini, mengadopsi dari ketentuan Pasal 294 $H I R$, yang dianggap sebagai pembuktian menurut undang-undang secara negatif.

Dari ketentuan Pasal 183 KUHAP tersebut, dibutuhkan minimal 2 (dua) alat bukti yang dapat menjadi pegangan hakim sebelum menjatuhkan putusan. Salah satu alat bukti yang diatur dalam hukum acara pidana adalah keterangan saksi, ialah apa yang saksi nyatakan di sidang pengadilan (Pasal 185 ayat (1) KUHAP). Jika dihubungkan dengan Pasal 1 butir 27 KUHAP, maka yang harus diterangkan oleh saksi dalam sidang adalah : 
a. apa yang saksi lihat sendiri;

b. apa yang saksi dengar sendiri, dan

c. apa yang saksi alami sendiri.

Namun faktanya keterangan saksi dalam KUHAP mengalami perubahan seiring dengan berkembangnya pengetahuan masyarakat di bidang tekhnologi, yaitu dengan adanya beberapa alat bukti berupa rekaman elektronik dalam tindak pidana pencucian uang sebagai alat bukti dalam praktek peradilan pidana. Di samping itu, juga telah diperkenalkan cara pemeriksaan saksi jarak jauh dengan memanfaatkan teknologi multimedia yang dikenal dengan teleconfrence. Dalam KUHAP tidak mengenal adanya bukti-bukti elektronik, maupun prosedur pemeriksaan saksi melalui sarana teknologi informasi teleconference, ataupun melalui media elektronik lainnya, misalnya surat elektornik (email).

Surat elektornik (email) jika dihubungkan dengan Pasal 184 ayat (1) KUHAP, adalah termasuk dalam kategori alat bukti surat sebagaimana di atur dalam Pasal 187 KUHAP. Alat bukti surat yang dimaksud adalah :

1. Berita acara dan surat lain, dokumen dalam bentuk yang sesuai dibuat pejabat umum yang berwenang;

2. Surat yang di buat menurut ketentuan peraturan perundang-undangan tentang suatu keadaan;

3. Surat keterangan ahli yang diminta secara resmi;

4. Surat lain yang hanya berlaku jika berhubungan dengan isi dari alat pembuktian lain.

Melihat penggolongan alat bukti surat yang diakui KUHAP, maka surat elektornik (email) dapat dimasukkan sebagai surat yang hanya berlaku, jika berhubungan dengan isi dari alat bukti lain. Karena itu, surat elektronik (email) merupakan alat bukti yang tidak dapat berdiri sendiri, sehingga membutuhkan alat bukti lainnya. Misalnya alat bukti keterangan saksi yang mengetahui pembuatan surat elektronik (email) itu, atau keterangan saksi ahli yang menerangkan keaslian surat elektronik (email) sebagai suatu alat bukti.

Pemanfaatan media elektronik khususnya email, sudah pasti akan menimbulkan adanya konsekuensi yang terjadi dalam penggunaan media tersebut, sebagai alat bukti dalam hukum acara pidana. Haruslah dipandang keberadaannya sebagai keterangan tambahan yang dapat menambah keyakinan hakim, dan dipahami secara objektif oleh Jaksa dan Terdakwa atau Penasehat Hukumnya, tetapi tidak diposisikan sebagai alat bukti yang secara limitatif telah diatur oleh undang-undang.

Dalam sistem pembuktian berdasarkan UU secara negatif terdapat prinsip bahwa hakim hanya boleh menjatuhkan pidana terhadap terdakwa, apabila alat bukti tersebut secara limitatif ditentukan oleh UU, dan didukung pula oleh adanya keyakinan hakim terhadap eksistensinya alat-alat bukti tersebut. Untuk memperkuat keyakinan hakim, bahwa terdakwa melakukan tindak pidana (delik), maka dipergunakan pembuktian melalui media elektronik dengan menggunakan media teleconference. Apabila disimak lebih jauh dalam dunia peradilan di Indonesia, pembuktian melalui media elektronik 
dengan menggunakan teleconference pernah dilakukan dalam persidangan Rahardi Ramelan, Pengadilan HAM Ad Hoc, perkara Abu Bakar Ba'asyir, dan kasus Bom Bali dengan terdakwa Ali Gufron Alias Muhklas diselenggarakan teleconference dari kesaksian Wan Min bin Wan Mat dari Malaysia.

Salah satu contoh adalah putusan Nomor 224/Pid.B/2003/ PN.Dps tanggal 2 Oktober 2003 atas nama terdakwa Ali Gufron Alias Muhklas, Majelis Hakim Pengadilan Negeri Denpasar dalam pertimbangan hukumnya memperkenankan digelarnya teleconference dikarenakan: (a) Bahwa memang benar teleconference tidak diatur dalam KUHAP karena pembuat undang-undang pada waktu itu tentunya tidak menyadari adanya revolusi teknologi informasi dan komunikasi yang sedemikian pesat, sehingga KUHAP tidak mampu mengantisipasinya. Apabila mengacu secara formal legalistik memang teleconference tidak sesuai ketentuan Pasal 160 ayat (1) huruf a dan Pasal 167 KUHAP yang menghendaki kehadiran saksi secara fisik di ruang persidangan. Dalam menggali, mengikuti, memahami dan mengejar kebenaran materiil dalam hukum pidana, aspek formal hendaknya bisa ditinggalkan secara selektif; (b) Pada dasarnya KUHAP dibuat dengan tujuan untuk mendapatkan kebenaran materiil sehingga teleconference hanyalah sekedar sarana untuk mencari keberanaran materiil tersebut, sehingga apa salahnya apabila dimanfaatkan. Dalam persidangan teleconference saksi juga bisa hadir di ruang sidang secara virtual. Semua pihak boleh juga menguji keterangan saksi dan keterangannyapun bisa didengar semua orang; (c) Bahwa keberatan Tim Penasehat hukum yang menyatakan ketidakberhasilan Jaksa Penuntut Umum tidak perlu disiasati dengan cara teleconference, karena Pasal 162 KUHAP mengaturnya. Majelis berpendapat karena saksi yang telah disumpah di penyidik kemudian dibacakan dan keterangan tersebut disamakan nilainya dengan keterangan saksi di bawah sumpah yang diucapkan di sidang (Pasal 162 (1), (2) KUHAP) karena saksi Wan Min bin Wan Mat layak apabila dihadirkan melalui media teleconference; (d) Bahwa terhadap keberatan Tim Penasehat Hukum yang menyatakan teleconference bertentangan dengan asas kompetensi Peradilan, majelis menyatakan tidak dapat diterima, karena apabila hal ini diterima akan mengakibatkan Peradilan Indonesia akan ketinggalan jaman dalam menghadapi revolusi teknologi dan informasi. Menurut Majelis Hakim, pemeriksaan saksi jarak jauh dengan menggunakan teleconference adalah merupakan salah satu wujud lahirnya Peradilan informasi yang berjangkauan global, lintas batas. Bagi majelis pemeriksaan melalui media teleconference mirip dengan cara pemeriksaan biasa di persidangan yang dilakukan secara langsung dan transparan. Fungsi dan tujuannya sejalan dengan proses peradilan itu sendiri, yaitu untuk mencari dan menemukan kebenaran materiil; (e) Bahwa terhadap kekhawatiran saksi Wan Min Wan Mat akan memberikan keterangan tidak dalam keadaan bebas/tertekan, hal ini berdasarkan Penetapan Majelis Hakim pemberian keterangan tersebut diberikan dihadapan seorang Hakim Anggota, Jaksa dan Penasehat Hukum dan disiarkan melalui media televise, sehingga majelis tidak menemukan indikasi saksi tersebut, memberikan keterangan dalam keadaan tidak bebas.

Hal ini berkesesuaian ketika Penasehat Hukum menanyakan, apakah saksi tersebut memberi keterangan dalam keadaan bebas, tidak ditekan, ia tidak dituntun dengan teks yang ada di depannya dan tidak ada petugas kepolisian di sekitarnya. Bahwa

Vol. 19 No. 1 Mei 2017 
berdasarkan Pasal 27 Undang-Undang Nomor 15 Tahun 2003 memungkinkan dipakainya alat bukti pemeriksaan berupa informasi yang diucapkan secara elektronik yang dalam hal ini dapat diartikan termasuk melalui media teleconference.

Pada tahun 2011 pemeriksaan saksi melalui teleconference kembali dipraktekkan dalam kasus Abu Bakar Ba'asyir terhadap 16 saksi yang akan memberi kesaksian, berdasarkan Surat Penetapan Pengadilan Negeri Jakarta Selatan Nomor : 148 / PEN.PID / 2011 / PN.Jkt.Sel. tanggal 10 Maret 2011, yang pada pokoknya mengabulkan permohonan pemeriksaan saksi secara teleconference atas 16 saksi tersebut dengan dasar dan argumentasi sebagai berikut:

1. Pasal 33 jo. Pasal 34 ayat (1) huruf c Undang-Undang Nomor 15 Tahun 2003 tentang Penetapan Peraturan Pemerintah Pengganti Undang-Undang Nomor 1 tahun 2002 tentang Pemberantasan Tindak Pidana Terorisme menjadi Undang-Undang;

2. Pasal 2 jo. Pasal 3 huruf c Peraturan Pemerintah Nomor 24 Tahun 2003 tentang Tata Cara Perlindungan Terhadap Saksi, Penyidik, Penuntut Umum, dan Hakim dalam Perkara Tindak Pidana Terorisme;

3. Pasal 9 ayat (1) dan ayat (3) Undang-Undang Nomor 13 Tahun 2006 tentang Perlindungan Saksi dan Korban

Praktek pembuktian melalui media elektronik dengan menggunakan penyadapan, misalnya dalam kasus Artalyta Suryani alias Ayin. KPK yang memperlihatkan gambar dan rekaman suara hasil penyadapan telepon Ayin dengan Jaksa Urip sebelum transaksi suap sebesar US\$ 660.000 pada persidangan di Pengadilan Tipikor. Dalam putusan Pengadilan Negeri Jakarta Pusat Nomor 07/PID.B/TPK/2008/ PN.JKT.PST tanggal 21 Juli 2008, menyatakan Artalyta Suryani alias Ayin telah terbukti secara sah, dan meyakinkan bersalah melakukan tindak pidana korupsi sebagaimana didakwakan dalam dakwaan Primair Pasal 5 ayat (I) huruf b UU No. 31 Tahun 1999 tentang Pemberantasan Tindak Pidana Korupsi sebagaimana telah diubah dengan UU No. 20 Tahun 2001 tentang Perubahan atas UU No. 31 Tahun 1999 tentang Pemberantasan Tindak Pidana Korupsi.

Dalam pertimbangan hukum, Majelis Hakim menghubungkan fakta hukum dengan keterangan saksi-saksi: Urip Tri Gunawan yang saling bersesuaian dengan saksi, Juliawan Superani, Djoko Widodo, Agus Heriyanto, Sambiyo, ahli DR. Joko Sarwono, dan barang bukti serta keterangan Terdakwa, rnaka perbuatan terdakwa Artalyta Suryani alias Ayin yang telah mernberikan uang sebesar US\$ 660.000 kepada saksi Urip Tri Gunawan, maka Majelis berpendapat bahwa unsur dengan memberi sesuatu telah terpenuhi.

Fakta tersebut di atas, menunjukkan bahwa pengungkapan Tindak Pidana korupsi melalui alat bukti rekaman suara sangat berpengaruh dan menguatkan aparat penegak hukum dalam mempertimbangkan untuk memperkuat alat bukti di muka persidangan. Terhadap pertimbangan hukum tersebut, bahwa hasil penyadapan tidak serta-merta dijadikan alat bukti dalam tindak pidana, namun harus disandingkan dan bersesuaian dengan keterangan saksi-saksi fakta serta pengakuan terdakwa, sehingga hemat penulis 
bahwa majelis hakim yang menyidangkan perkara atas nama Artalyta Suryani alias Ayin belum melakukan terobosan hukum (judge made law).

Praktek pembuktian melalui media elektronik dengan menggunakan penyadapan telah diuji melalui Mahkamah Konstitusi berdasarkan Perkara No. 20/PUU-XIV/2016, yang dimohonkan oleh Drs. Setya Novanto. Dalam permohonannya, pemohon memohonkan pengujian terhadap UU No. 11 Tahun 2008 tentang Informasi dan Transaksi Elektronik dan UU No. 20 Tahun 2001 tentang Perubahan Atas UU No. 31 Tahun 1999 tentang Pemberantasan Tindak Pidana Korupsi terhadap UUD NRI Tahun 1945. Mahkamah Konstitusi yang merupakan peradilan tingkat pertama dan terakhir, menjatuhkan putusan mengenai frasa "informasi elektronik dan/atau dokumen elektronik" dalam Pasal 5 ayat (1) dan ayat (2) serta Pasal 44 huruf b UU ITE mutatis mutandis berlaku pula bagi Pasal 26A UU Tipikor. Dalam pertimbangannya, Mahkamah Konstitusi mempertimbangkan bahwa Mahkamah perlu menegaskan kembali pertimbangan Putusan Mahkamah Konstitusi Nomor 006/PUU-1/2003, bertanggal 30 Maret 2004 yang kemudian ditegaskan kembali dalam Putusan Nomor 5/PUUVIII/2010, bertanggal 24 Februari 2011 tentang penyadapan yang menyatakan: " Mahkamah memandang perlu untuk mengingatkan kembali bunyi pertimbangan hukum Mahkamah dalam Putusan Nomor 006/PUU-1/2003 tersebut, oleh karena penyadapan dan perekaman pembicaraan merupakan pembatasan terhadap HAM, di mana pembatasan demikian hanya dapat dilakukan dengan undang-undang, sebagaimana ditentukan oleh Pasal 28J ayat (2) UUD NRI Tahun 1945. Undang-undang dimaksud itulah yang selanjutnya harus merumuskan, antara lain, siapa yang berwenang mengeluarkan perintah penyadapan dan perekaman dapat dikeluarkan setelah diperoleh bukti permulaan yang cukup, yang berarti bahwa penyadapan dan perekaman pembicaraan itu untuk menyempurnakan alat bukti, ataukah justru penyadapan dan perekaman pembicaraan itu sudah dapat dilakukan untuk mencari bukti permulaan yang cukup. Sesuai dengan perintah Pasal 28J ayat (2) UUD NRI Tahun 1945, semua itu harus diatur dengan undang-undang guna menghindari penyalahgunaan wewenang yang melanggar hak asasi".

Dari pertimbangan putusan Mahkamah tersebut, sampai saat ini belum ada UU yang secara khusus mengatur tentang penyadapan sebagaimana yang diamanatkan oleh putusan Mahkamah. Oleh karena itu, untuk mengisi kekosongan hukum tentang penyadapan yang termasuk di dalamnya perekaman, agar tidak semua orang dapat melakukan penyadapan, maka penafsiran bersyarat yang dimohonkan oleh Pemohon terhadap frasa "informasi elektronik dan/atau dokumen elektronik" dalam Pasal 5 ayat (1) dan ayat (2) serta Pasal 44 huruf b UU ITE dan Pasal 26A UU Tipikor beralasan hukum sepanjang dimaknai frasa "informasi elektronik dan/atau dokumen elektronik" sebagai alat bukti dilakukan dalam rangka penegakan hukum atas permintaan kepolisian, kejaksaan, dan/atau institusi penegak hukum lainnya, yang ditetapkan berdasarkan UU sebagaimana ditentukan dalam Pasal 31 ayat (3) UU ITE.

Menurut Mahkamah, bahwa sebenarnya kekhawatiran yang dikemukakan Pemohon dalam permohonannya tidak perlu ada karena telah ditegaskan dalam Pasal 31 ayat (3) yang menyatakan, "Kecuali intersepsi sebagaimana dimaksud pada ayat (1) dan 
ayat (2), intersepsi yang dilakukan dalam rangka penegakan hukum atas permintaan kepolisian, kejaksaan, dan/ atau institusi penegak hukum lainnya yang ditetapkan berdasarkan undang-undang". Namun demikian, untuk mencegah terjadinya perbedaan penafsiran terhadap Pasal 5 ayat (1) dan ayat (2) UU ITE, Mahkamah harus menegaskan bahwa setiap intersepsi harus dilakukan secara sah, terlebih lagi dalam rangka penegakan hukum. Oleh karena itu, Mahkamah dalam amar putusan di bawah ini akan menambahkan kata atau frasa "khususnya" terhadap frasa yang dimohonkan pengujian oleh Pemohon, agar tidak terjadi penafsiran bahwa putusan ini akan mempersempit makna, atau arti yang terdapat di dalam Pasal 5 ayat (1) dan ayat (2) UU ITE;

Penegasan Mahkamah tersebut, perlu dilakukan dalam rangka due process of law, sehingga perlindungan terhadap hak-hak warga negara sebagaimana diamanatkan oleh UUD NRI Tahun 1945 terpenuhi. Selain itu, juga merupakan pemenuhan atas Pasal 1 ayat (3) UUD NRI Tahun 1945 yang menyatakan Negara Indonesia adalah negara hukum. Kesemuanya itu dimaksudkan agar tidak terjadi tindakan sewenang-wenang atas hak privasi warga negara yang dijamin dalam UUD NRI Tahun 1945;

Mahkamah Konstitusi perlu juga mempertimbangkan mengenai bukti penyadapan berupa rekaman pembicaraan sesuai dengan hukum pembuktian. Dalam hukum pembuktian, rekaman pembicaraan adalah real evidence atau physical evidence. Pada dasarnya barang bukti, adalah benda yang digunakan untuk melakukan suatu tindak pidana atau benda yang diperoleh dari suatu tindak pidana, atau benda yang menunjukkan telah terjadinya suatu tindak pidana. Dengan demikian, rekaman pembicaraan dapat dijadikan bukti sebagai barang yang menunjukkan telah terjadi suatu tindak pidana. Persoalannya adalah apakah rekaman pembicaraan merupakan bukti yang sah dalam hukum acara pidana? Untuk menilai rekaman tersebut, merupakan bukti yang sah adalah dengan menggunakan salah satu parameter hukum pembuktian pidana yang dikenal dengan bewijsvoering, yaitu penguraian cara bagaimana menyampaikan alat-alat bukti kepada hakim di pengadilan. Ketika aparat penegak hukum menggunakan alat bukti yang diperoleh dengan cara yang tidak sah atau unlawful legal evidence, maka bukti dimaksud dikesampingkan oleh hakim atau dianggap tidak mempunyai nilai pembuktian oleh pengadilan.

Terhadap Putusan No. 20/PUU-XIV/2016 yang dimohonkan oleh Drs. Setya Novanto tersebut, penulis sependapat sebab, terhadap penyadapan perlu dilakukan dalam rangka due process of law, sehingga perlindungan terhadap hak-hak warga negara sebagaimana diamanatkan oleh UUD NRI Tahun 1945 terpenuhi, dan dilakukan dalam rangka penegakan hukum atas permintaan kepolisian, kejaksaan, dan/atau institusi penegak hukum lainnya yang ditetapkan berdasarkan undang-undang.

Terkait dengan hasil penyadapan tersebut dapat diajukan sebagai bukti yang sah dalam hukum acara pidana, seharusnya penilaian hasil penyadapan tersebut, merupakan bukti yang sah dengan menggunakan salah satu parameter hukum pembuktian pidana yang dikenal dengan bewijsvoering, yaitu penguraian cara bagaimana menyampaikan alat-alat bukti kepada hakim di pengadilan. Ketika aparat penegak hukum menggunakan alat bukti yang diperoleh dengan cara yang tidak sah atau unlawful legal evidence, maka 
bukti dimaksud dikesampingkan oleh hakim atau dianggap tidak mempunyai nilai pembuktian oleh pengadilan.

Penggunaan surat elektronik (email) yang dipergunakan sebagai ruang untuk berbagi pengalaman pun berujung pada pencemaran nama baik. Kasus yang terjadi antara RSUD Tangerang dan Dr. Ira Simatupang, Sp.OG yang juga seorang dokter di RSUD Tangerang, disebabkan penyebaran email yang berisi pencemaran nama baik. Gugatan dilayangkan ke Pengadilan Negeri Tangerang sejak Juli 2012 lalu. Yang menjadi dasar bagi hakim dalam memasukkan surat elektronik sebagai alat bukti yang sah dalam proses pembuktian di persidangan, adalah dilihat dalam ketentuan Pasal 184 ayat (1) KUHAP, tidak terdapat pengaturan mengenai alat bukti surat elektronik.

Kasus yang terjadi antara RSUD Tangerang dan Dr. Ira Simatupang, Sp.OG tersebut, membawa konsekuensi atas pertimbangan Majelis Hakim Pengadilan Negeri Tangerang yang menggunakan alat bukti elektronik adalah berdasarkan UU No. 11 Tahun 2008 tentang Informasi dan Transaksi Elektronik, adalah belum dapat diberlakukan atau diterapkan terhadap Terdakwa Dr. Ira Simatupang, Sp.OG, oleh karena pemberlakuan secara efektif dari UU dimaksud adalah 2 (dua) Tahun setelah diundangkan, yakni tanggal 21 April 2010 sedangkan peristiwanya terjadi pada tanggal 15 Juli 2010.

Pembuktian melalui media elektronik, menunjukkan telah beberapa kali diselenggaraan baik atas permintaan JPU maupun Penasehat Hukum. Namun demikian, tidak semua permohonan pemeriksaan saksi melalui teleconference dapat dilakukan dan diterima oleh Pengadilan, seperti kasus Schapelle Leigh Corby yang bermohon untuk pemeriksaan melalui teleconference, tidak dapat diterima padahal penasehat hukum Corby, Erwin Siregar mendalilkan bahwa penggunaan teleconference itu, merupakan instrumen untuk mencari kebenaran materil. Akan tetapi Mahkamah Agung tidak menerima pemeriksaan saksi melalui teleconference, dengan dalil bahwa dalam sistem hukum civil law, yurisprudensi bersifat persuasif. Sehingga tak ada kewajiban bagi hakim menggunakan teleconference, dan bukan pula merupakan keharusan menurut hukum acara pidana yang berlaku di Indonesia untuk menggunakan teleconference dalam proses pemeriksaaan saksi.

Jika dikaitkan dengan KUHAP pemeriksaan saksi melalui teleconference memang bertentangan dengan Pasal 160 ayat (1) dan Pasal 167 ayat (1) KUHAP. Pada Pasal 160 ayat (1) huruf a KUHAP menyebutkan "saksi di panggil ke ruang sidang seorang demi seorang menurut urutan yang dipandang sebaik-baiknya oleh hakim ketua sidang setelah mendengar pendapat penuntut umum, terdakwa atau penasehat hukum terdakwa". Kemudian Pasal 167 ayat (1) KUHAP menentukan, "setelah saksi memberikan keterangan, ia tetap hadir di sidang kecuali hakim ketua sidang memberi izin untuk meninggalkannya". Sehingga berdasarkan ketentuan tersebut, kehadiran seorang saksi secara fisik dituntut untuk hadir dan memberi kesaksian dalam persidangan.

Demikian pula Pasal 185 ayat (1) KUHAP menyatakan bahwa "keterangan saksi sebagai alat bukti ialah apa yang saksi nyatakan di depan sidang pengadilan". Sehingga kata menyatakan di depan sidang disini menjadi tidak jelas (abscur), oleh karena KUHAP sendiri tidak menjelaskan atau menegaskan dalam memberikan keterangan di 
depan sidang saksi harus hadir secara langsung (fisik) ke persidangan untuk memberikan keterangan. Di kalangan praktisi hukum kalimat yang menyatakan "keterangan saksi dinyatakan di depan persidangan" menimbulkan celah untuk ditafsirkan, terlebih celah ini secara eksplisit termuat dalam ketentuan Pasal 9 UU No. 13 Tahun 2006 tentang Perlindungan Saksi dan Korban, yang menegaskan ada tiga pilihan saksi tak harus dihadirkan ke pengadilan, yaitu :

1. Saksi diperbolehkan memberi keterangan secara tertulis di hadapan pejabat seperti notaris, hakim, atau camat;

2. Keterangan saksi dapat diperiksa lewat teleconference;

3. Pemeriksaannya seperti mistery guest, yang memberikan keterangan dalam ruangan khusus.

Keterangan saksi melalui sarana teleconference, sebenarnya telah memenuhi Pasal 185 ayat (1) KUHAP yang pada pokoknya menyatakan "keterangan saksi sebagai alat bukti ialah apa yang saksi nyatakan di depan sidang pengadilan", dimana keterangan saksi secara teleconference juga dinyatakan di depan persidangan, akan tetapi tidak secara langsung (fisik) hadir dalam persidangan. Dari ketentuan tersebut, memang secara tekstual tidak dituntut kehadiran seorang saksi secara fisik di ruang sidang. Akan tetapi Pasal 160 ayat (1) huruf a dan Pasal 167 KUHAP, pada intinya mengatur bahwa kehadiran fisik seorang saksi adalah mutlak. Namun kenyataannya, untuk mencari dan menegakan kebenaraan materiil yang berujung pada keadilan terhadap hal yang tekstual tersebut, dalam praktik relatif ditinggalkan.

Pemikiran mengenai pemeriksaan tanpa hadirnya terdakwa sejatinya telah ada jauh sebelumnya, hal ini terbukti dari putusan Mahkamah Agung RI Nomor : $661 \mathrm{~K} / \mathrm{Pid} / 1988$ tanggal 19 Juli 1991 dengan kaidah hukum : "keterangan saksi yang tidak dapat hadir di persidangan karena suatu halangan yang sah pada dasarnya tetap di sumpah. Keterangannya tersebut sama nilainya dengan kesaksian di bawah sumpah".

Dengan dasar yuridis Pasal 5 ayat (1) UU No. 48 Tahun 2009 tentang Kekuasaan Kehakiman, hakim sebagai penegak hukum dan keadilan wajib menggali, mengikuti dan memahami nilai-nilai hukum rasa keadilan yang hidup dalam masyarakat. Sehingga dalam menggali, mengikuti, memahami dan mengejar kebenaran materiil dalam hukum pidana, maka aspek formal hendaknya ditinggalkan secara selektif. Terlepas dari salah tidaknya terdakwa, hakim telah menggunakan nalarnya untuk menggunakan bukti tersebut (disamakan) sebagai alat bukti surat yang diatur di dalam Pasal 184 KUHAP.

Secara normatif dan dari segi kepastian hukum, khususnya penerapan teleconference sebagai upaya penyampaian keterangan saksi di persidangan, terkesan membingungkan terutama perihal persoalan antara hukum yang seharusnya (das sollen) dengan hukum dalam kenyataannya (das sein), sehingga perlu segera diluruskan dan diselaraskan.

Apabila Pasal 3 KUHAP dihubungkan dengan Pasal 284 ayat (2) KUHAP, nyata sekali bahwa "peradilan harus dilakukan menurut cara yang diatur dalam undangundang ini (KUHAP)". Namun demikian, hukum acara pidana itu tidak hanya diatur di 
dalam KUHAP, tetapi juga terdapat di luar KUHAP sebagai ketentuan khusus acara pidana yang terdapat pada undang-undang tertentu.

Kontroversi yang terjadi tentang penggunaan teleconference ataupun dengan media elektronik lainnya, sebenarnya disebabkan terdapatnya dua kubu pendapat dikalangan para ahli hukum, dan hal ini diperkuat dengan hasil wawancara penulis dengan Hakim pada Pengadilan Negeri Jakarta Pusat, dan Pengadilan Negeri Jakarta Selatan, Jaksa Penuntut Umum pada Kejaksaan Negeri Jakarta Pusat, dan Kejaksaan Negeri Jakarta Selatan, dan Komisioner KPK. Tampaknya hakim lebih bertitik tolak pada substansial justice dalam pencarian kebenaran materiil. Sedangkan Jaksa dan KPK lebih mengedepankan paradigma formalisme, dan substansial justice.

Pada dasarnya KUHAP dibuat dengan tujuan untuk mendapatkan kebenaran materiil, sehingga teleconference hanyalah sekadar sarana untuk mencari kebenaran materiil, sehingga apa salahnya apabila dimanfaatkan. Dalam persidangan teleconference saksi juga bisa hadir di ruang sidang secara virtual. Semua pihak boleh juga menguji keterangan saksi dan keterangannyapun bisa didengar semua orang.

Pemeriksaan saksi jarak jauh dengan menggunakan teleconference, adalah merupakan salah satu wujud lahirnya Peradilan informasi yang berjangkauan global, lintas batas, sehingga pemeriksaan melalui media teleconference sebisa mungkin mirip dengan cara pemeriksaan saksi biasa di persidangan yang dilakukan secara langsung dan transparan. Fungsi dan tujuannya sejalan dengan proses peradilan itu sendiri, yaitu untuk mencari dan menemukan kebenaran materiil. Dengan demikian peradilan Indonesia tidak akan ketinggalan jaman dalam menghadapi revolusi teknologi dan informasi.

\section{Kekuatan Hukum Pembuktian Melalui Media Elektronik Dalam Prespektif Sistem Peradilan Pidana Indonesia}

Perkembangan hukum di Indonesia khususnya hukum pidana formil, yakni dengan dibentuknya UU No. 8 Tahun 1981 (KUHAP), adalah merupakan salah satu sikap progresif untuk segera menghapuskan hukum peninggalan kolonial. Dengan berlakunya KUHAP, nyata sekali telah menimbulkan perubahan fundamental, baik secara konsepsional maupun secara implementasi terhadap tata cara penyelesaian perkara pidana di Indonesia, yakni perubahan dalam cara berpikir yang mengakibatkan pada perubahan sikap, dan cara bertindak para aparat penegak hukum secara keseluruhan.

Dalam konteks ini, mekanisme peradilan pidana sebagai suatu proses, atau disebut "criminal justice process" yang dimulai dengan proses penangkapan, penggeledahan, penahanan, penuntutan, dan pemeriksaan di muka sidang pengadilan, serta diakhiri dengan pelaksanaan pidana di lembaga pemasyarakatan".

Dengan demikian hal pokok yang memegang peranan dalam proses pemeriksaan perkara pidana, adalah pembuktian melalui alat bukti yang sah sebagaimana diatur dalam Pasal 184 KUHAP.

Perlu diakui bahwa sejak lahirnya KUHAP sampai munculnya penggunaan pembuktian melalui media elektronik, khususnya teleconference dalam persidangan 
perkara pidana, menunjukkan bahwa terdapat beberapa hal yang dianggap inovasi dalam prespektif hukum acara, terutama menyangkut sistem pembuktian dimana perkembangan teknologi informasi dan telekomunikasi dewasa ini, telah turut mewarnai perkembangan dunia hukum dan peradilan itu sendiri. adapun kelemahan-kelemahan KUHAP perlu segera diatasi dan dicarikan solusinya.

Persidangan pengadilan melalui teleconference memang tidak diatur dalam KUHAP, sehingga berakibat masalah legalitasnya bersifat sangat interpretatif. Namun demikian, pemanfaatan teleconference sebagai alat bukti di persidangan, dari berbagai pemikiran tampaknya sudah mulai mengerucut bahwa teleconference paling dekat korelasinya dengan alat bukti saksi.

Sistem pembuktian di Indonesia, adalah perpaduan antara sistem conviction-in time (vrijbewijk) dan sistem pembuktian positif (positief wettelijk stelsel). Dengan demikian, keyakinan hakim merupakan suatu hal yang penting dalam sistem pembuktian. Sebagai suatu keyakinan, maka sifatnya konviktif dan subyektif, sehingga sulit diuji secara obyektif. Untuk mendapatkan keyakinan (conviction), hakim harus dapat memahami latar belakang kehidupan seseorang, perilaku dan bahasa tubuhnya di sidang pengadilan secara fisik berhadap-hadapan.

Penggunaan teknologi teleconference yang menyajikan gambar secara detail dan kualitas suara secara jelas tanpa gangguan (noice), memungkinkan hakim untuk mengetahui secara langsung sorot mata, roman muka, maupun bahasa tubuh (gestures) yang ditunjukkan oleh seorang di muka persidangan. Dengan demikian, pada prinsipnya kehadiran seseorang di muka persidangan sebagaimana dimaksud hadir secara fisik, juga dapat dipenuhi dengan menggunakan teknologi teleconference.

Teleconference memang tepat untuk menggantikan kehadiran saksi di muka persidangan secara virtual. Namun perlu mendapat perhatian juga dalam hal alokasi waktu meminta keterangan saksi, hal ini penting karena waktu yang sempit dan terbatas akan sangat berpengaruh terhadap kualitas kedalaman informasi yang diperoleh dari saksi. Jika permasalahan alokasi waktu ini, tidak mendapatkan solusi yang tuntas, maka sia-sialah seluruh usaha menghadirkan saksi secara virtual di muka siding, karena kurangnya informasi dan kedalaman keterangan yang dibutuhkan.

Mengenai kekuatan teleconference dan media elektronik lainnya dalam proses pembuktian perkara pidana menurut KUHAP, ditegaskan sekali lagi bahwa KUHAP telah menentukan secara limitatif alat bukti yang sah, dan tata cara penggunaan alat bukti tersebut, sehingga memiliki kekuatan hukum pembuktiannya. Yang dimaksud dengan kekuatan alat bukti tiada lain, adalah "seberapa jauh nilai alat bukti itu masingmasing dalam hukum pembuktian"; yang meliputi :

a. Kekuatan alat bukti keterangan saksi;

b. Kekuatan alat bukti keterangan ahli;

c. Kekuatan alat bukti surat;

d. Kekuatan alat bukti petunjuk;

e. Kekuatan alat bukti keterangan terdakwa. 
Keterangan saksi tampaknya ditetapkan sebagai alat bukti yang paling utama, karena hampir tidak ada perkara pidana yang luput dari keterangan saksi.

Masuknya teleconference dalam persidangan perkara pidana di Indonesia, menunjukkan bahwa hukum tidak statis, melainkan berkembang sesuai perkembangan ilmu pengetahuan dan teknologi. Kenyataan ini, dikuatkan oleh Sunaryati Hartono, bahwa pembangunan dalam bidang hukum akan meliputi :

1. Menyempurnakan (membuat sesuatu yang lebih baik);

2. Mengubah agar menjadi lebih baik dan modern;

3. Mengadakan sesuatu yang sebelumnya belum ada; atau

4. Meniadakan sesuatu yang terdapat dalam sistem lama, karena tidak diperlukan dan tidak cocok dengan sistem baru.

Penggunaan teleconference dalam persidangan, sebagai suatu terobosan hendaknya tidak menimbulkan kesan diskriminatif ditinjau dari segi kemanfaatan secara normatif maupun secara sosiologis. Apabila fakta ini, mencerminkan kekurangankekurangan dari KUHAP dalam mengakomodasikan harapan para pencari keadilan (justiabelen), diperlukan suatu pengkajian kembali terhadap KUHAP dalam rangka mewujudkan Ius Constituendum.

Adapun jenis-jenis teleconference yang pernah digunakan dalam persidangan perkara pidana, adalah jenis teleconference dengan menggunakan sistem kawat, atau telepon (hanya didengar suaranya saja, seperti dalam kasus pelanggaran HAM di TimTim), dan teleconference dengan menggunakan sistem optik (audio visual, seperti dalam kasus Abu Bakar Ba'asyir). Di beberapa negara maju khususnya di Inggris, peradilan sistem konvensional senantiasa diterapkan berdampingan dengan tata cara pemeriksaan persidangan bentuk baru (modern). Bentuk-bentuk baru dimaksud, sebagaimana dijelaskan oleh M. Yahya Harahap adalah teleconference, yang bentuknya dapat berupa:

a. Behind a screen atau disebut To give evidence from behind a screen; saksi memberi keterangan (diperiksa di belakang layar), sehingga, (i). saksi tidak berhadapan langsung dengan terdakwa pada saat saksi memberikan keterangan, (ii). dengan syarat terdakwa harus mendengar sepenuhnya keterangan saksi.

Tata cara behind a screen, terutama diterapkan dalam pemeriksaan perkara "perkosaan" (rape) dan "penyalahgunaan seksual" (sexual abuse) terhadap "anak kecil". Tujuannya untuk menghindari saksi atau anak kecil dari "trauma", serta untuk menghindari "siksaan berat" bagi saksi jika berhadapan langsung dengan terdakwa di persidangan.

b. By live television link: keterangan saksi diberikan melalui "tayangan langsung" yang disambungkan ke ruang sidang:

(i). saksi tidak langsung in person hadir dan berhadapan dengan terdakwa di ruang sidang, (ii). saksi berada di tempat lain, tetapi pada saat memberi keterangan dilakukan dengan sistem dan teknik by live television link di ruang siding; (iii). Dengan demikian wajah dan suara saksi pada saat memberi keterangan dapat dilihat dan didengar terdakwa "di layar monitor". 
c. Videotape record atau "kamera" : keterangan saksi direkam dalam videotape record atau kamera (the hearing may be held in videotape record or camera), dan rekaman itulah yang dipertunjukkan di ruang sidang.

Sehubungan dengan penggunaan teleconference tersebut, ketentuan yang dapat dijadikan sebagai dasar guna mengukur kekuatan dan penilaian alat bukti, antara lain dengan memperhatikan dan mengkaji ketentuan-ketentuan yang terdapat dalam Pasal 183 sampai dengan Pasal 189 KUHAP jo Pasal 3 KUHAP dan Pasal 284 ayat (2) KUHAP; Pasal 5 ayat (1) dan Pasal 10 ayat (1) UU No. 48 Tahun 2009 tentang Kekuasaan Kehakiman.

Berbicara mengenai pengaturan teleconference dan media elektronik lainnya, maka yang dimaksud dengan pengaturan disini adalah menunjuk kepada suatu pengaturan yang dibuat secara tertulis, jelas, dan tegas (lex scripta, lex certa, lex stricta), sehingga secara legitimate (sah), UU dalam konteks hukum sebagai suatu sistem baik secara horizontal maupun vertikal harus merupakan produk legislatif. Artinya perkataan hukum tertulis atau UU di sini hanya UU dalam arti formil atau UU yang dibuat oleh Pemerintah dan atau DPR dengan tanpa mengabaikan principles of legality.

Tentang pengaturan teleconference, secara de facto KUHAP tidak mengatur mengenai model teleconference yang dapat digunakan sebagai sarana penyampaian keterangan saksi dalam sistem pembuktiannya. Yang ada, yakni dalam Pasal 185 ayat (1) KUHAP menjelaskan bahwa "keterangan saksi sebagai alat bukti ialah apa yang saksi nyatakan di sidang pengadilan". Demikian juga dalam peraturan lainnya yang terkait, khususnya UU No. 36 Tahun 1999 jo Peraturan Pemerintah No. 52 Tahun 2000, tidak mengatur secara tersurat tentang teleconference, melainkan hanya mengatur teknis operasional penggunaan jaringan telekomunikasi, yang di antaranya dapat digunakan untuk penyelenggaraan teleconference dalam berbagai keperluan.

Dalam undang-undang tertentu, yang mengatur ketentuan khusus acara pidana, seperti UU No. 15 Tahun 2003 Tentang Terorisme, dan UU No. 20 Tahun 2001 Tentang Pemberantasan Tindak Pidana Korupsi, sesuai penerapan asas lex specialis de rogat lex generalis, ternyata juga tidak mengatur ketentuan tentang keterangan saksi yang dapat disampaikan melalui teleconference. Yang diatur hanyalah ketentuan tentang perluasan alat bukti yang sudah ada dalam KUHAP. Pasal 26 A UU No. 20 Tahun 2001 mengatur alat bukti elektronik sebagai perluasan dari alat bukti petunjuk sebagaimana dijelaskan dalam Pasal 188 ayat (2) KUHAP, bahwa: "alat bukti petunjuk sebagaimana dimaksud dalam Pasal 188 ayat (2) KUHAP, juga dapat diperoleh melalui alat bukti elektronik". Demikian juga di dalam Pasal 27 UU No. 15 Tahun 2003 mengakui adanya alat bukti elektronik selain alat bukti yang telah diatur di dalam KUHAP. Jelaslah, bahwa teleconference yang digunakan untuk mendengarkan keterangan saksi B.J Habibie dari Hamburg-Jerman terkait dengan kasus korupsi (kasus Bulog), adalah bukan sebagai alat bukti elektronik sebagaimana dimaksudkan dalam Pasal 26 A UU No. 20 Tahun 2001.

Penggunaan teleconference dalam kasus Abu Bakar Ba'asyir (melalui perkara Nomor: 547/Pid.B/2003/P.N.Jkt.Pst) yang proses acaranya akhirnya murni berdasarkan KUHAP, tidak berdasarkan UU No. 15 Tahun 2003, berarti pembuktiannya harus 
berpedoman kepada Pasal 184 KUHAP jo Pasal 183 KUHAP dan Pasal 185 ayat (1) KUHAP.

UU No. 48 Tahun 2009 tentang Kekuasaan Kehakiman, menentukan bahwa apa yang hakim pertimbangkan di dalam praktik peradilan, tidak boleh menyimpang dari asas dan kaidah hukum pidana (baik materiil maupun formil). Dengan demikian, model atau cara pembuktian melalui media elektronik tersebut, sebagai sarana untuk menyampaikan keterangan saksi menurut Pasal 185 ayat (1) KUHAP, adalah keterangan saksi yang harus disampaikan secara fisik (in person) di sidang pengadilan. Hal ini perlu dimaknai sebagai upaya dari pembentuk UU, agar supaya situasi ruang sidang yang khidmat dapat membentuk aspek psikologis dari saksi tersebut, dalam memberikan keterangan yang benar dan jujur, sehingga hakim memperoleh keyakinan guna mewujudkan kebenaran materiil.

Selain itu, cara pembuktian melalui media elektronik tersebut, terkesan bertentangan dengan asas yang berlaku dalam hukum acara pidana, khususnya asas "peradilan yang harus dilakukan dengan cepat, tetapi sederhana dan biaya ringan, serta bebas, jujur, dan tidak memihak (diskriminatif) yang dalam praktek harus diterapkan secara konsekuen dalam seluruh tingkat peradilan. Para hakim sendiri harus tetap bebas dari pengaruh, kecuali atas perintah hukum, konstitusi, keputusan yang mempertimbangkan pemikiran sehat, preseden hukum, dan perintah hati nurani para hakim sendiri.

Penilaian barang bukti atau alat bukti elektronik tidak bisa dibatasi, atau dipersyaratkan peruntukkannya melalui peraturan perundang-undangan. Yang terpenting, barang bukti dan alat bukti tergantung orisinalitas, dan otentisitasnya dalam rangka kepentingan pembuktian perkara pidana, perdata, tata usaha negara, atau bidang hukum lain. Karena penggunaan teknologi elektronik bersifat netral, bisa menjadi barang bukti dan berubah menjadi alat bukti tergantung perbuatan (pidana) yang menyertainya.

Penggunaan teknologi elektronik tidak bisa dibendung, karena perkembangan teknologi informasi sudah menjangkau semua aspek kehidupan. Namun penggunaan dan sasarannya dibatasi oleh etika pergaulan bermasyarakat yang bisa berakibat suatu perbuatan dicela masyarakat. pembatasan barang bukti atau alat bukti elektronik dalam undang-undang, justru bertentangan dengan asas penyelenggaraan peradilan pidana yang dijamin konstitusi. Sebab, proses peradilan seringkali dibutuhkan alat bukti kuat dan lengkap guna menjamin kepastian hukum yang adil berdasarkan alat-alat bukti yang ditetapkan undang-undang.

Sebagai solusinya, guna melengkapi dan menyempurnakan maksud dari Pasal 185 ayat (1) KUHAP berdasarkan Pasal 3 KUHAP jo. Pasal 284 ayat (2) KUHAP, perlu segera diatur tentang penggunaan teleconference dimaksud. Adapun dasar pertimbangan yang umum, bahwa negara Indonesia adalah negara hukum dimana secara de facto dan de jure bahwa:

(1) Sistem hukum di negara Indonesia mengutamakan hukum tertulis. 
(2) Asas dan kaidah hukum (pidana khususnya pidana formil) yang berlaku itu penting dan harus diterapkan secara konsekwen, sebab asas dan kaidah itu merupakan ruh hidupnya hukum.

(3) Pilar-pilar utama hukum (kepastian, keadilan, dan kemanfaatan) harus dihormati untuk mencegah runtuhnya wibawa hukum.

(4) Asas-asas yang terdapat dalam principles of legality merupakan asas penting dan utama bagi kepastian hukum dan kepastian keadilan.

(5) Tujuan dari hukum acara pidana itu sendiri yakni melaksanakan proses hukum yang adil atau due process of law (yang unsur-unsurnya antara lain pembuktian, dan melaksanakan pengadilan yang adil atau equal justice) untuk mencari dan mewujudkan kebenaran materiil.

Mengenai kesaksian dengan mempergunakan teleconference, sebenarnya telah mendapat pengakuan dan telah diatur dalam Pasal 9 ayat (3) UU No. 13 Tahun 2006 tentang Perlindungan Saksi dan Korban, yang berbunyi: "Saksi dan/atau Korban sebagaimana dimaksud pada ayat (1) dapat pula didengar kesaksiannya secara langsung melalui sarana elektronik dengan didampingi oleh pejabat yang berwenang". Arti katakata melalui sarana elektronik menurut penulis adalah merupakan pengakuan secara tersirat terhadap teleconference dalam hal pembuktian melalui media elektronik.

Penetapan hakim tentang penggunaan teleconference terhadap contoh-contoh kasus di atas, semata-mata harus dianggap sebagai upaya yang dapat dilakukan oleh hakim berdasarkan Pasal 10 ayat (1) jo Pasal 5 ayat (1) UU No. 48 Tahun 2009 Tentang Kekuasaan Kehakiman. Fakta ini, merupakan i terobosan dalam sistem pembuktian perkara pidana. Oleh karenanya, harus dianggap sebagai konstruksi hukum yang dilakukan oleh quasi legislator, yang disebabkan oleh kekosongan hukum yang mengatur teknologi tersebut. Untuk memperkokoh pilar-pilar hukum dalam rangka law enforcement, hendaknya produk quasi lagislator ini, dapat menjadi input bagi pembentuk undang-undang di masa yang akan datang (ius constituendum). Artinya langkah-langkah dalam hukum acara itu, tidak hanya menyangkut masalah prosedural saja, akan tetapi perlu pengaturan yang tegas dan jelas untuk menghindari diskriminasi hukum serta salah tafsir. Apalagi pemanfaatan teknologi teleconference ini, memerlukan biaya yang besar sehingga harus dipertimbangkan dengan hasil yang akan diperoleh dari penggunaan, atau pemanfaatan teknologi teleconference tersebut.

Upaya mengharmonisasikan antara asas legalitas (baik dalam pemahamannya dari aspek hukum pidana materiil maupun formil) dengan Pasal 5 ayat (1) dan Pasal 10 ayat (1) UU No. 48 Tahun 2009 Tentang Kekuasaan Kehakiman, perlu direalisasikan tidak hanya sekedar retorik, sehingga keterangan saksi yang dilaksanakan, atau dilakukan melalui media teleconference memiliki kekuatan hukum menurut sistem pembuktian perkara pidana.

\section{PENUTUP}

Pembuktian melalui media elektronik di persidangan pidana, kendatipun Kitab UndangUndang Hukum Acara Pidana tidak mengaturnya secara tegas, namun tampaknya teori pembuktian berdasarkan undang-undang secara negatif telah diperluas, sehingga hakikat

Vol. 19 No. 1 Mei 2017 
kebenaran dari pemeriksaan saksi teleconference tetap sama nilainya dengan saksi yang tidak hadir di persidangan karena saksi tersebut telah disumpah. Kekuatan hukum pembuktian melalui media elektronik dalam prespektif sistem peradilan pidana Indonesia, dengan mempergunakan pendekatan normatif, tidak dapat disangkal lagi bahwa untuk menciptakan kepastian hukum dan rasa keadilan melalui proses pembuktian perkara pidana, diperlukan adanya kesamaan persepsi dan keselarasan di dalam menggunakan undang-undang positif.

\section{DAFTAR PUSTAKA}

Andi Hamzah, Hukum Acara Pidana Indonesia, Cetakan kedua, Jakarta: Sinar Grafika, 2002 ,

Aloysius Wisnuboroto dan Gregorius Widiartana, 2005, Pembaharuan Hukum Acara Pidana, Citra Aditya Bakti, Bandung.

A.Z. Abidin Farid, 1983, Pembuktian dan Alat-Alat Bukti.Jakarta:Ghalia Indonesia.

C.F.G Sunaryati Hartono, 1982, Hukum Ekonomi Pembangunan Indonesia, Binacipta, Bandung.

H. M. Arsyad Sanusi, et. al, 2003, Analisis dan Evaluasi Hukum Tentang Pemanfaatan Media Elektronik (Teleconference) Untuk Pembuktian Dalam Hukum Acara Pidana, Badan Hukum Nasional Departemen Hukum dan HAM RI, Jakarta.

Romli Atmasasmita, 1996, Sistem Peradilan Pidana, Putra A. Bardin, Bandung. , 2011, Sistem Peradilan Pidana Kontemporer, Jakarta: Kencana.

Waluyadi. Hukum Pembuktian dalam Perkara Pidana untuk Mahasiswa dan Praktisi Bandung, Mandar Maju. 2004. 